\title{
Mixing layer height on the North China Plain and meteorological evidence of serious air pollution in southern Hebei
}

Xiaowan Zhu et al.

Correspondence to: Guiqian Tang (tgq@dq.cern.ac.cn)

The copyright of individual parts of the supplement might differ from the CC BY 3.0 License. 
Table S1 Specific information of the observation sites on the NCP.

\begin{tabular}{|c|c|c|c|c|}
\hline Cityname & Abbreviation & $\begin{array}{c}\text { Province } \\
\text { or } \\
\text { municipality }\end{array}$ & Longitude & Latitude \\
\hline Beijing $^{\mathrm{a}, \mathrm{b}, \mathrm{c}}$ & $\mathrm{BJ}$ & Beijing & $116.32^{\circ} \mathrm{E}$ & $39.90^{\circ} \mathrm{N}$ \\
\hline Tianjin ${ }^{\mathrm{a}, \mathrm{b}}$ & $\mathrm{TJ}$ & Tianjin & $117.20^{\circ} \mathrm{E}$ & $39.13^{\circ} \mathrm{N}$ \\
\hline Shijiazhuang ${ }^{\mathrm{a}, \mathrm{b}}$ & SJZ & Hebei & $114.26^{\circ} \mathrm{E}$ & $38.03^{\circ} \mathrm{N}$ \\
\hline Langfang $^{\mathrm{a}}$ & $\mathrm{LF}$ & Hebei & $116.70^{\circ} \mathrm{E}$ & $39.53^{\circ} \mathrm{N}$ \\
\hline Tangshan ${ }^{\mathrm{a}}$ & TS & Hebei & $118.02^{\circ} \mathrm{E}$ & $39.68^{\circ} \mathrm{N}$ \\
\hline Qinhuangdao $^{\mathrm{a}, \mathrm{b}}$ & QHD & Hebei & $119.57^{\circ} \mathrm{E}$ & $39.95^{\circ} \mathrm{N}$ \\
\hline Zhangjiakou $^{\mathrm{a}}$ & ZJK & Hebei & $114.92^{\circ} \mathrm{E}$ & $40.90^{\circ} \mathrm{N}$ \\
\hline Chengde $^{\mathrm{a}}$ & $\mathrm{CD}$ & Hebei & $117.89^{\circ} \mathrm{E}$ & $40.97^{\circ} \mathrm{N}$ \\
\hline Laoting ${ }^{\mathrm{b}, \mathrm{c}}$ & $\mathrm{LT}$ & Hebei & $118.90^{\circ} \mathrm{E}$ & $39.31^{\circ} \mathrm{N}$ \\
\hline Cangzhou $^{\mathrm{a}}$ & $\mathrm{CZ}$ & Hebei & $116.83^{\circ} \mathrm{E}$ & $38.33^{\circ} \mathrm{N}$ \\
\hline Baoding $^{\mathrm{a}}$ & $\mathrm{BD}$ & Hebei & $115.48^{\circ} \mathrm{E}$ & $38.85^{\circ} \mathrm{N}$ \\
\hline Hengshui $^{\mathrm{a}}$ & HS & Hebei & $115.72^{\circ} \mathrm{E}$ & $37.72^{\circ} \mathrm{N}$ \\
\hline Xingtai $^{\mathrm{b}, \mathrm{c}}$ & XT & Hebei & $114.48^{\circ} \mathrm{E}$ & $37.05^{\circ} \mathrm{N}$ \\
\hline Handan $^{\mathrm{a}}$ & HD & Hebei & $114.47^{\circ} \mathrm{E}$ & $36.60^{\circ} \mathrm{N}$ \\
\hline Dezhou $^{\mathrm{a}}$ & $\mathrm{DZ}$ & Shandong & $116.29^{\circ} \mathrm{E}$ & $37.45^{\circ} \mathrm{N}$ \\
\hline Liaocheng $^{\mathrm{a}}$ & $\mathrm{LC}$ & Shandong & $115.97^{\circ} \mathrm{E}$ & $36.45^{\circ} \mathrm{N}$ \\
\hline $\operatorname{Jinan}^{\mathrm{a}}$ & $\mathrm{JN}$ & Shandong & $116.98^{\circ} \mathrm{E}$ & $36.67^{\circ} \mathrm{N}$ \\
\hline Binzhou $^{\mathrm{a}}$ & $\mathrm{BZ}$ & Shandong & $118.02^{\circ} \mathrm{E}$ & $37.22^{\circ} \mathrm{N}$ \\
\hline Dongying $^{\mathrm{a}}$ & DY & Shandong & $118.49^{\circ} \mathrm{E}$ & $37.46^{\circ} \mathrm{N}$ \\
\hline $\mathrm{Zibo}^{\mathrm{a}}$ & $\mathrm{ZB}$ & Shandong & $118.05^{\circ} \mathrm{E}$ & $36.78^{\circ} \mathrm{N}$ \\
\hline Weifang $^{\mathrm{a}}$ & WF & Shandong & $119.06^{\circ} \mathrm{E}$ & $36.68^{\circ} \mathrm{N}$ \\
\hline
\end{tabular}

Table S2 Seasonal averages of the MLH at the BJ, SJZ, TJ and QHD stations in NCP from December 2013 to November 2014.

\begin{tabular}{ccccc}
\hline Station & Spring(m) & Summer(m) & Autumn(m) & Winter(m) \\
\hline BJ & $655 \pm 166$ & $722 \pm 169$ & $531 \pm 169$ & $493 \pm 131$ \\
SJZ & $489 \pm 142$ & $623 \pm 161$ & $404 \pm 147$ & $347 \pm 153$ \\
TJ & $627 \pm 189$ & $655 \pm 165$ & $493 \pm 169$ & $436 \pm 178$ \\
QHD & $498 \pm 217$ & $447 \pm 153$ & $451 \pm 146$ & $467 \pm 180$ \\
\hline
\end{tabular}

Table S3 Annual means of T, RH, MLH and $\mathrm{V}_{\mathrm{c}}$ for the BJ, SJZ, TJ and QHD stations in NCP from December 2013 to November 2014.

\begin{tabular}{lllcl}
\hline & $\mathrm{T}\left({ }^{\circ} \mathrm{C}\right)$ & $\mathrm{RH}(\%)$ & $\mathrm{MLH}(\mathrm{m})$ & $\mathrm{V}_{\mathrm{c}}\left(\mathrm{m}^{2} \mathrm{~s}^{-1}\right)$ \\
\hline BJ & 13.7 & 51.2 & 594 & 3054.5 \\
SJZ & 13.5 & 65.7 & 464 & 2045.4 \\
TJ & 14.1 & 57.0 & 546 & \\
QHD & 10.9 & 68.6 & 465 & 3021.0 \\
\hline
\end{tabular}




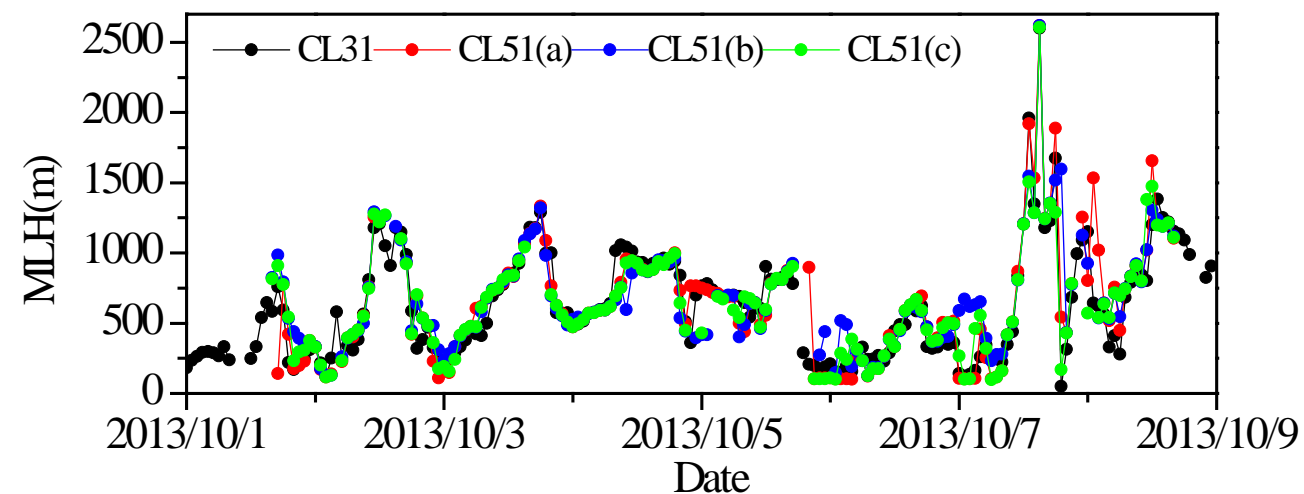

Fig. S1 Comparison between the MLH measured by CL31 and by CL51 (a), CL51 (b) and CL51(c).
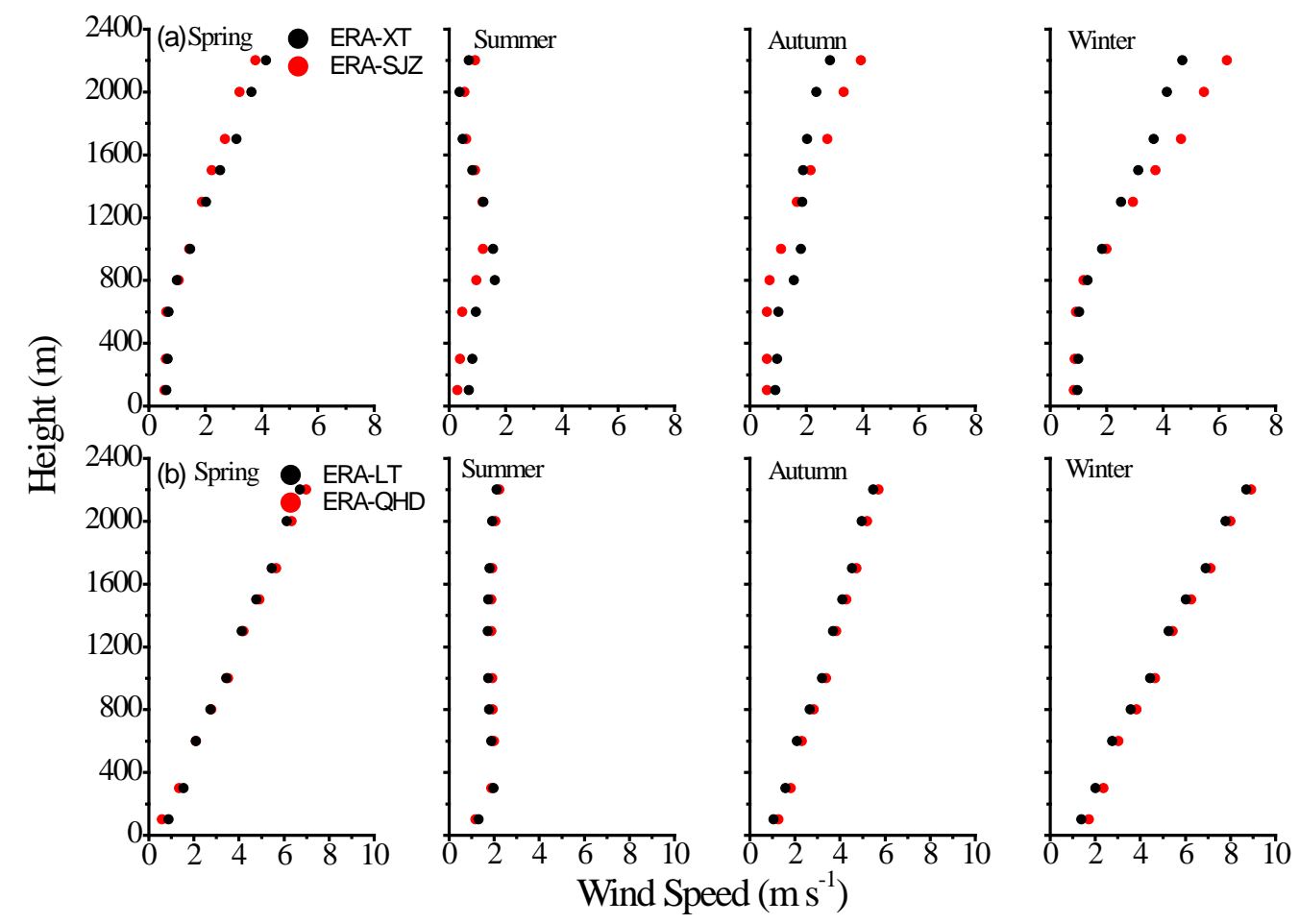

Fig. S2 Comparisons of the wind speed profile between (a) the XT and SJZ stations and (b) the LT and QHD stations with reanalysis data. 

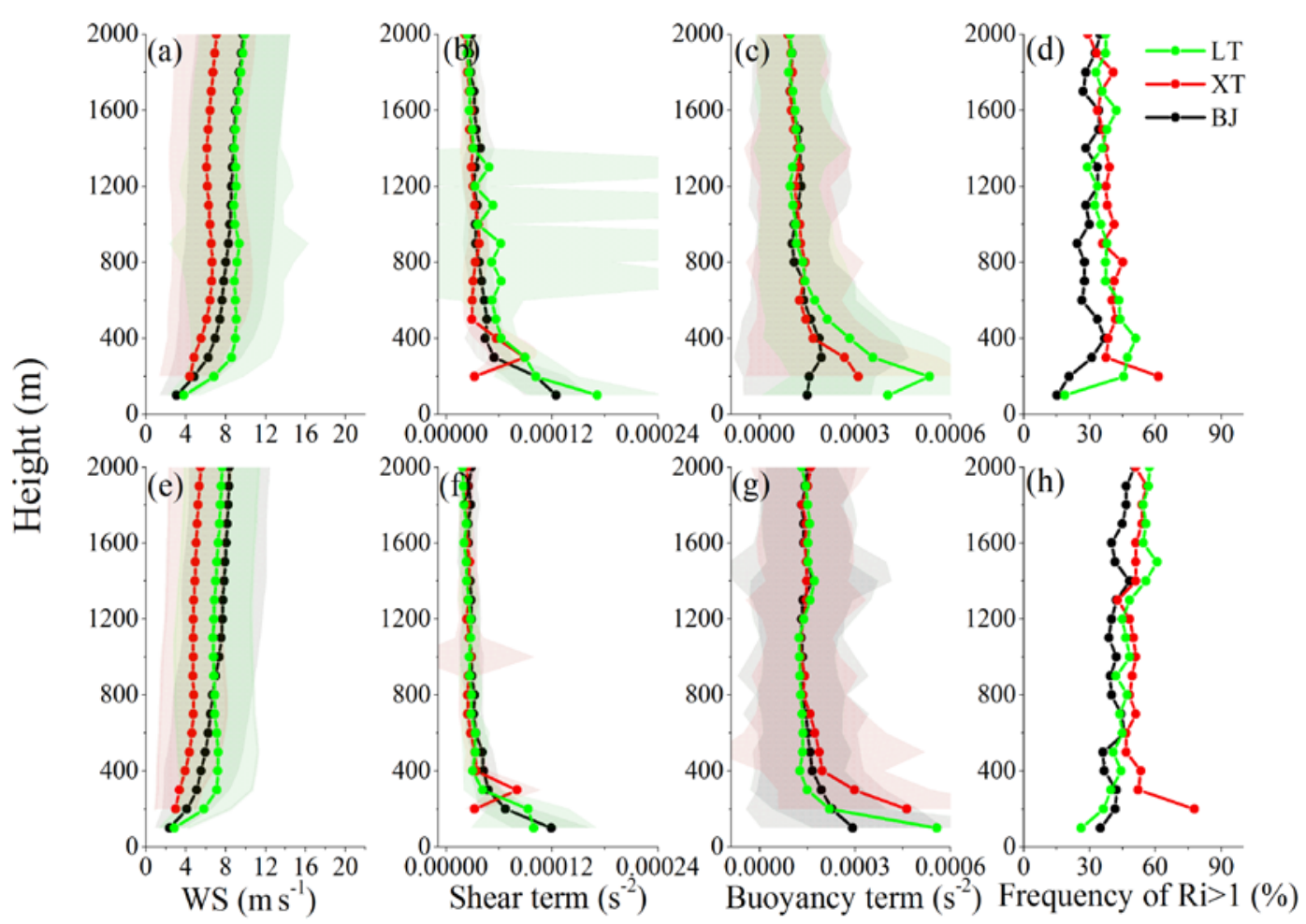

Fig.S3 Vertical profiles of (a, e) horizontal WS, (b, f) shear term, (c, g) buoyancy term and (d, h) frequency of $R i>1$ at the BJ, XT and LT stations in spring (upper panel) and autumn (lower panel).

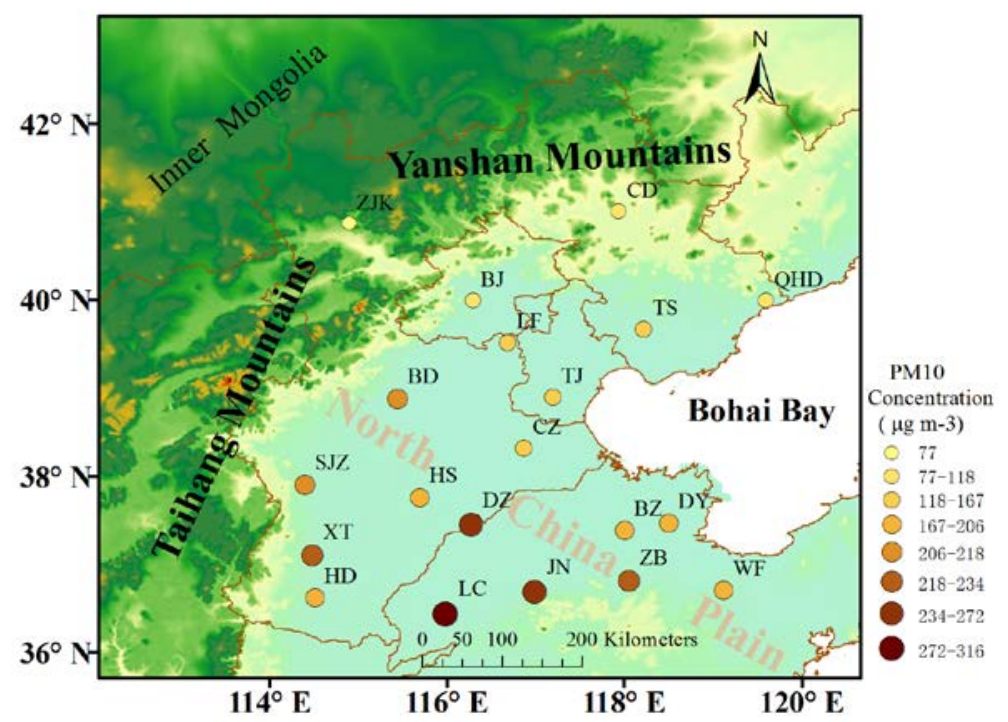

Fig. S4 Distributions of $\mathrm{PM}_{10}$ concentrations at the NCP. The $\mathrm{PM}_{10}$ observation sites (ZJK, CD, BJ, QHD, TJ, LF, TS, CZ, BD, SJZ, HS, XT, HD, DZ, LC, JN, BZ, DY, $\mathrm{ZB}$ and WF) are marked in the map with black abbreviations. The sizes and colors of the circular marks are representative of the annual means of near-ground $\mathrm{PM}_{10}$ concentrations; the larger and darker the circle is, the larger the concentrations is. 

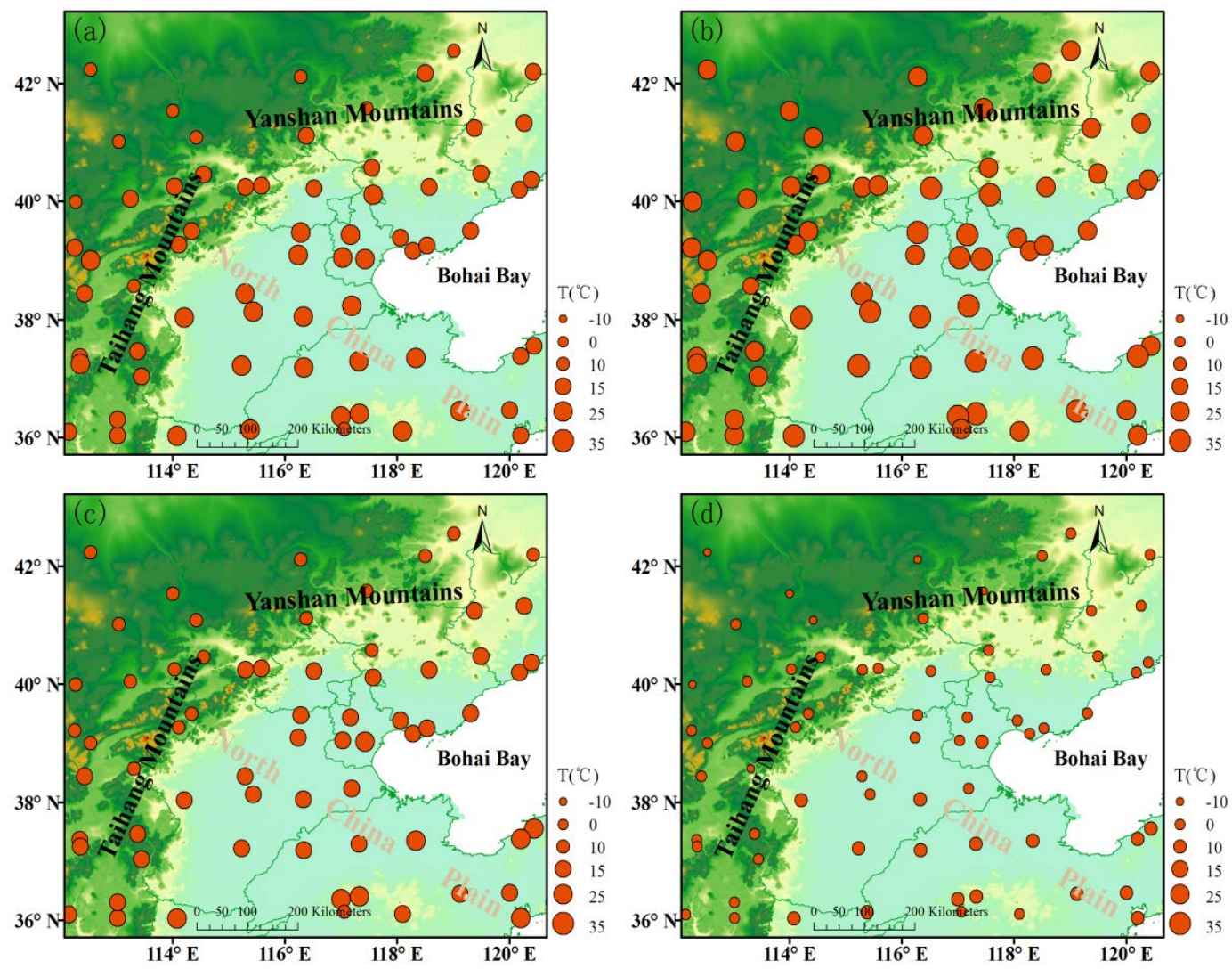

Fig. S5 Seasonal distributions of T in the NCP: (a) spring, (b) summer, (c) autumn and (d) winter.
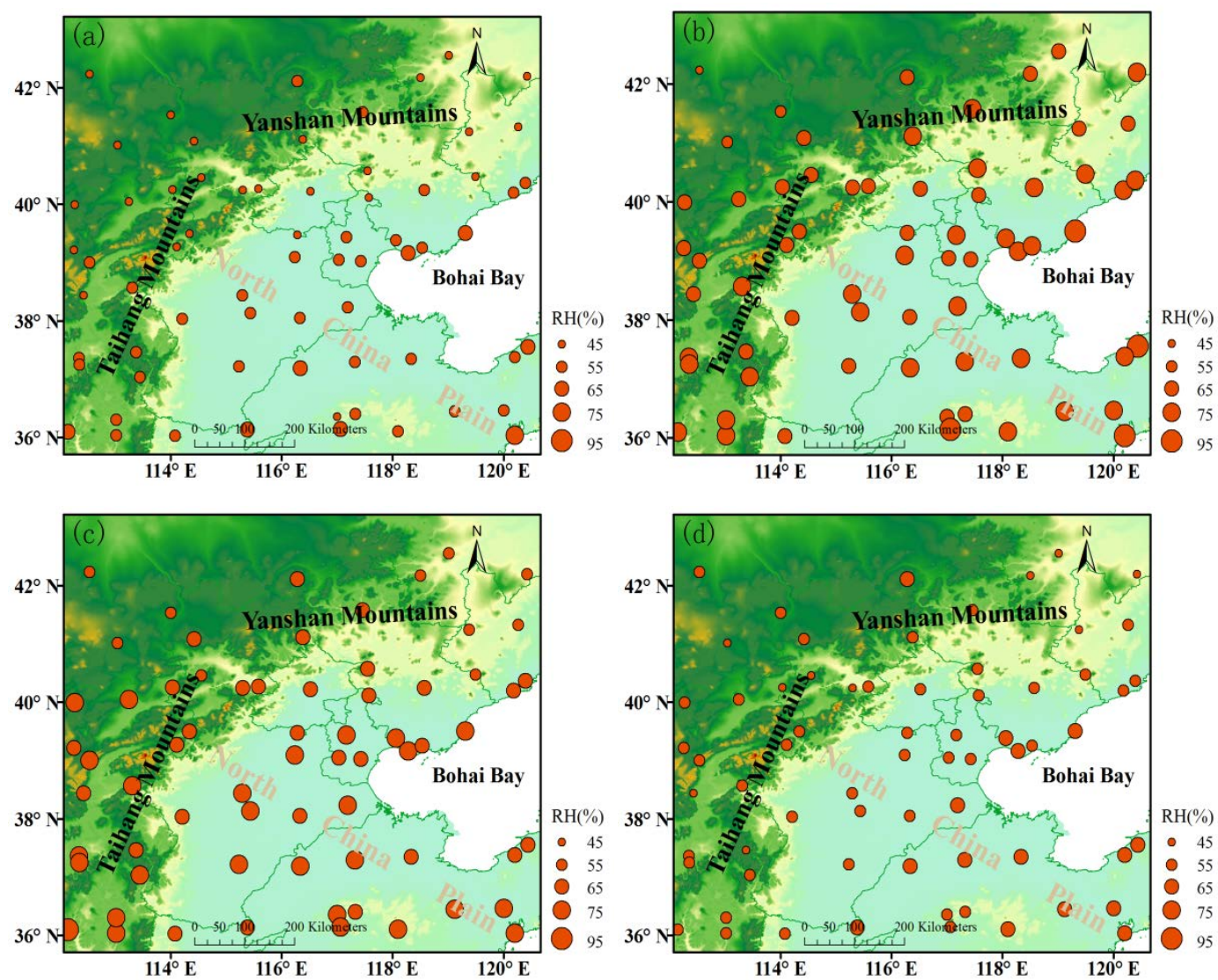

Fig. S6 Seasonal distributions of RH in the NCP: (a) spring, (b) summer, (c) autumn 
and (d) winter. 